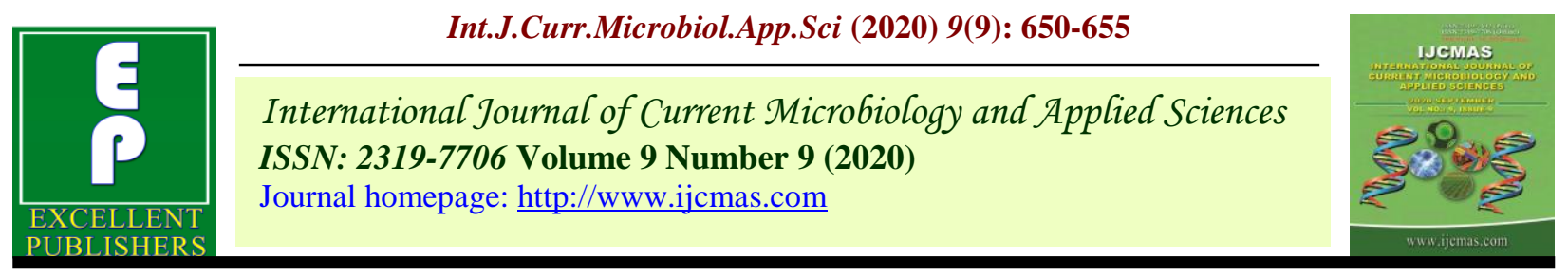

Original Research Article

https://doi.org/10.20546/ijcmas.2020.909.082

\title{
Nutritional Quality Evaluation of Popular Indian Fried Snacks Based on Cowpea
}

\author{
Dashrath Bhati* and Rita Singh Raghuvanshi \\ Department of Food and Nutrition, College of Home Science, GB Pant University of \\ Agriculture and Technology, India \\ *Corresponding author
}

\begin{abstract}
A B S T R A C T
Keywords

Cowpea, Indian snacks, Black-eyed beans, Chemical parameter, Ready to eat (RTE)

Article Info

Accepted:

07 August 2020

Available Online:

10 September 2020

Fried snacks are popular among young Indian population. An experiment was conducted for nutritional quality evaluation of the fried cowpea snacks. Boondi, $s e v$, enrobed nuts and fried nuts were formulated by using cowpea. These products were evaluated for proximate composition, mineral content i.e. iron, calcium and free radical scavenging activity. Nutritional quality evaluation was done at Department of Foods and Nutrition, College of Home Science, GB Pant University of Agriculture and Technology. Cowpea snacks were high in protein, fibre and mineral ash and ranging from $10.25-18.43 \%, 0.55-2.95 \%$ and $2.52-$ $4.94 \%$ respectively. Calcium and iron content was ranged between 1.30 to 2.03 $\mathrm{mg} / 100 \mathrm{gm}$ and 5.01 to $9.14 \mathrm{mg} / 100 \mathrm{gm}$ respectively. Present study reveals that cowpea snacks could be considered the best in terms of nutritional quality, especially for young children.
\end{abstract}

\section{Introduction}

Snacks are small, light, very handy, and simple meals which do not replace main meals. These snacks add to the total food and nutrient intake of individuals. In India people love to eat snacks and considered to be a habit. These snacks are usually chips, namkeens, lightly processed or fried and ready-to-eat food products. This made the processed food industry more dynamic and productive. Resulting all above, gobs of conventional foods especially fried snacks are available in Indian market.
Recent years, Indian snack market has undergone various changes due to high competition among multi-national companies which lead to high standards for the regional and small food processers. Local and regional food processors also play an important role through developing distinctive products and flavours by using local and indigenous food produce. With all these contributory factors Indians also have an emotional connection with eating snacks and this continues to drive the market towards growth. The increasing per capita income of the people, modern lifestyle, urbanisation and increase in the 
number of working mothers etc. give wings to the snacks industry (Noor et al., 2012). Revenue in the Snack Food segment amounts to US\$5,839m in 2020. The market is expected to grow annually by $6.3 \%$ CAGR 2020-2023

(https://www.statista.com/outlook/40110000/ 119/snack-food/ind ia). The total salty snacks market in India is estimated at Rs 29,000 crore, with an annual growth of $24 \%$. The health snacks sub-segment is estimated to be around $2 \%$ of the overall snacks market (https://economictimes.indiatimes.com/indust ry/cons-products/fmcg/itc-jumps-on-healthysnacks-ban

dwagon/articleshow/70301268.cms

?from $=\mathrm{mdr}$ ).

Cowpea (Vigna unguiculata) is one of the versatile pulse crops due to its wide uses and applications as food for humans; however it is not very much popular in India. It is an important grain legume in developing countries like India. To mitigate the problem of chronic energy deficiency, protein energy malnutrition and for increasing per capita availability of pulses, researchers are focusing on production and evaluation of physical characteristics and nutritional composition of uncommon pulses like cowpea.

Improved varieties of pulse crops has high production, mature early, grow well and fit for inter cropping especially for rice and wheat in context of Uttarakhand, wherein the lands are marginal with low productivity and rain fed agriculture (Pandey and Singh, 2006). Pantnagar University has developed many early maturing grain cowpea varieties under pulse improvement programme. As per recommendation of scientist working under this programme, cowpea snacks were developed by using cowpea variety PL-1. This paper deals with the nutritional composition of the developed cowpea snacks.

\section{Materials and Methods}

Different permutation and combinations were employed for formulation of popular Indian fried snacks by using cowpea (Pant Lobia- 1) as base ingredient. After standardization and sensory evaluation flour products i.e. sev, boondi, enrobed nuts (peanuts were enrobed by using cowpea flour with added spices) and fried cowpea nuts were finalized for nutritional quality evaluation. The following parameters were evaluated:

\section{Proximate composition}

All the developed cowpea products were analysed for the proximate composition- i.e. moisture, protein ( $\mathrm{N} \times$ 6.25), crude fat (ether extraction), ash and crude fibre (AOAC, 1995). The carbohydrate, content was calculated by difference, i.e. 100, the sum of the per cent of ash, protein, fat and fibre (AOAC, 1995). Energy value was calculated by multiplying the physiological values obtained for carbohydrate, protein and fat, with 4, 4 and 9 respectively and adding up the values (AOAC, 1995).

\section{Mineral content}

All the four developed cowpea products were analysed for calcium and iron content through Atomic Absorption Spectrophotometer method suggested by Bishnoi and Brar, 1988.

\section{Free radical scavenging activity}

The DPPH (2,2-diphenyl-1-picrylhydrazyl) is a free radical reagent and an easy, precise, and accurate method for the analysis of free radical scavenging activity of the food product. The 2, 2-diphenyl-1-picryl-hydrazyl produces a violet solution in alcohol. It is reduced in the presence of an antioxidant molecule. Antioxidant activity of the methanol extract of the developed products 
and standard were assessed on the basis of the radical scavenging effect of the stable 2,2diphenyl-1-picrylhydrazyl hydrate radical (DPPH). The diluted working solutions of the test samples were prepared in methanol. Gallic acid was used as the standard in solutions ranging from $5 \times 10^{-4}$ to $4 \times 10^{-3} \mathrm{mg}$ $\mathrm{ml}^{-1}$. DPPH solution $0.135 \mathrm{mM}$ was prepared in methanol. Then $2 \mathrm{ml}$ of this DPPH solution was mixed with $2 \mathrm{ml}$ of sample solutions (ranging from $1 \mathrm{mg} \mathrm{ml}^{-1}$ to $8 \mathrm{mg} \mathrm{ml}^{-1}$ ) and the standard solution were tested separately.

These solution mixtures were kept in the dark for $30 \mathrm{~min}$ and optical density was measured at $517 \mathrm{~nm}$ using ECIL make spectrophotometer against methanol. $2 \mathrm{ml}$ of methanol with $2 \mathrm{ml}$ of DPPH solution was used as control. The optical density was recorded and percentage of inhibition was calculated using the formula ((Saxena et al., 2015 and Shimada et al., 1992)) given below:

$\%$ of inhibition of DPPH activity $=(\mathrm{A}-\mathrm{B} / \mathrm{A})$ $\times 100$

Where, A is optical density of the control and $B$ is optical density of the sample.

The free radical scavenging activity of the methanolic extracts of the test samples were expressed as the IC 50 value $(\mathrm{mg} / \mathrm{ml})$ i.e., the concentration necessary to decrease the DPPH concentration by $50 \%$.

\section{Results and Discussion}

\section{Proximate composition}

Proximate content is an important parameter to assess the basic nutritional quality of any food product. The data on proximate composition (dry weight basis) of four fried snacks based on cowpea are summarized under table 1. Ash content in foodstuff is assessed after destruction of organic matter present in it. Thus it may not necessarily be exactly equivalent to the mineral matter as some changes may occur due to volatilization or some interaction between constituents (Ranganna 1986). The ash content in the developed product was higher and approximately similar in enrobed nuts $(4.94 \%)$ and sev $(4.17 \%)$ followed by fried nuts $(3.29 \%)$ and boondi $(2.52 \%)$.

Fat provides energy and aids in transport of fat soluble vitamins, insulates and protects internal tissues and contributes to important cell processes (Jones et al., 1985 and Pamela et al., 2005).

The analysed crude fat, with the true fat (triglycerides), other material soluble in ether such as phospholipids, sterols, essential oils and fat soluble pigments are also present in it (Ranganna 1986). Crude fat content was among the cowpea based snacks recorded lowest in fried cowpea nuts $(26.74 \%)$ and highest in enrobed nuts (42.42\%).

Crude fiber is the organic residue which remains after the food sample has been treated under standardized conditions with petroleum spirit, boiling dilute sulphuric acid, boiling dilute sodium hydroxide solution and alcohol. The crude fiber consists largely of cellulose together with a little lignin. The crude fiber content was noted higher i.e. $2.95 \%$ in enrobed nuts followed by 1.32 in fried cowpea nuts, $0.73 \%$ in sev and $0.55 \%$ in boondi.

Protein content in the developed snacks was recorded maximum for enrobed nuts (18.43 $\%$ ) followed by boondi (12.75\%), sev (11.82 $\%)$ and fried nuts $(10.25 \%)$. Enrobed fried nuts were prepared by enrobing cowpea flour added with spices on roasted peanuts, hence the protein content of enrobed fried nuts were higher. 
Table.1 Mean values of proximate composition of the cowpea snacks (gm/100gm)

\begin{tabular}{|c|c|c|c|c|c|c|c|}
\hline & Moisture & Ash & Fat & Fiber & Protein & CHO & Energy \\
\hline Sev & $2.01 \pm 0.074$ & $4.17 \pm 0.034$ & $36.94 \pm 0.321$ & $0.73 \pm 0.067$ & $11.82 \pm 0.602$ & $49.41 \pm 0.815$ & $573.31 \pm 1.487$ \\
\hline Boondi & $5.89 \pm 0.319$ & $2.52 \pm 0.070$ & $34.97 \pm 0.922$ & $0.55 \pm 0.018$ & $12.72 \pm 0.358$ & $55.50 \pm 0.927$ & $582.59 \pm 4.599$ \\
\hline Enrobed Nuts & $1.26 \pm 0.191$ & $4.94 \pm 0.051$ & $42.42 \pm 0.207$ & $2.95 \pm 0.118$ & $18.43 \pm 0.355$ & $32.54 \pm 0.583$ & $585.66 \pm 0.415$ \\
\hline Fried cowpea nuts & $1.30 \pm 0.151$ & $3.29 \pm 0.053$ & $26.74 \pm 0.125$ & $1.32 \pm 0.067$ & $10.25 \pm 0.261$ & $59.71 \pm 0.403$ & $520.49 \pm 0.397$ \\
\hline
\end{tabular}

Note: dry weight basis \pm Standard deviation

Table.2 Mean values of calcium and iron content in cowpea snacks (mg/100gm)

\begin{tabular}{|c|c|c|}
\hline Cowpea products & Calcium & Iron \\
\hline Sev & $1.75 \pm 0.056$ & $7.43 \pm 0.107$ \\
\hline Boondi & $1.38 \pm 0.028$ & $5.01 \pm 0.087$ \\
\hline Enrobed Nuts & $1.71 \pm 0.124$ & $6.07 \pm 0.282$ \\
\hline Fried Nuts & $2.03 \pm 0.071$ & $9.14 \pm 0.492$ \\
\hline
\end{tabular}

Note: dry weight basis \pm Standard deviation

Fig.1

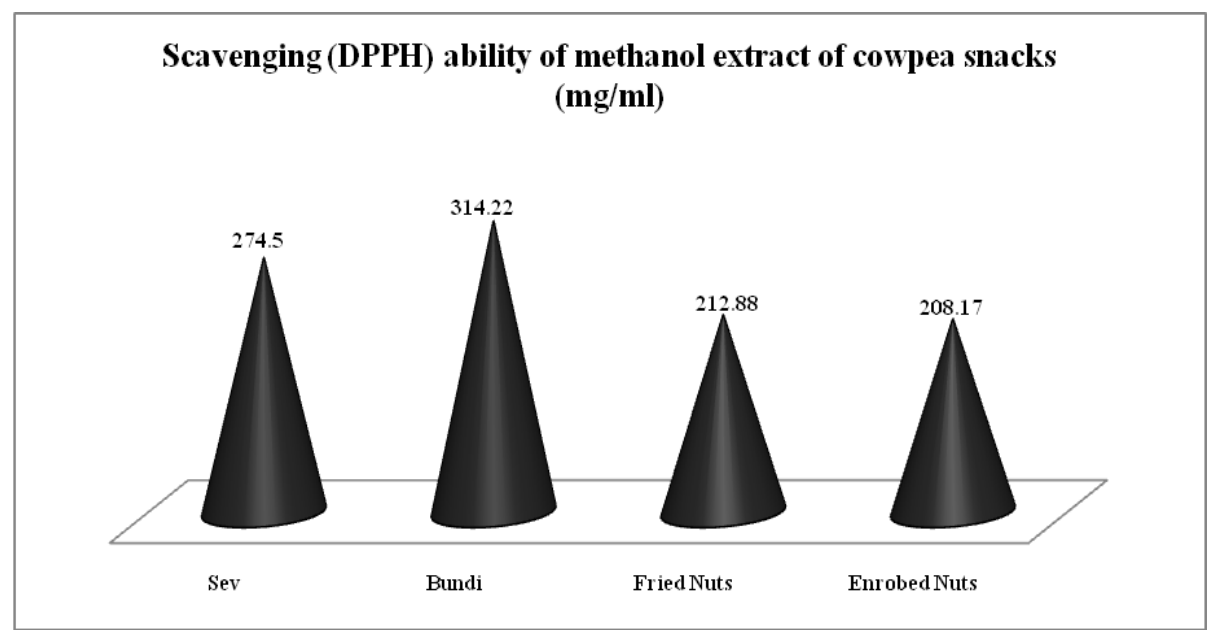

\section{Calcium and iron content}

The developed snacks were also analysed for calcium and iron content and presented under table 2. Highest calcium and iron content was noted in fried nuts i.e. 2.03 and 9.14 $\mathrm{mg} / 100 \mathrm{gm}$ respectively. Marginal difference was noted in calcium and iron content was observed for sev and enrobed nuts. The present study reveals that all the developed snacks were rich source of iron content.

\section{Free radical scavenging activity}

The determination of the antioxidant activity of cowpea product extract was based on the DPPH radical scavenging activity through the $\mathrm{IC}_{50}$ parameter, which represents the concentration of the material necessary to inhibit $50 \%$ of free radicals. Thus, a lower $\mathrm{IC}_{50}$ value shows a superior ability to neutralize free radicals and potential antioxidant content. The scavenging ability of methanol extract of the cowpea snacks are 
represented as $\mathrm{IC}_{50}$ of DPPH radical is shown in Fig 1. Enrobed nuts followed by fried cowpea nuts had $208.17 \mathrm{mg} / \mathrm{ml}$ and $212.88 \mathrm{mg} / \mathrm{ml}$ free radical scavenging activity respectively. The results of the present study revealed that the fried snacks also exhibit the antioxidant property.

Kushwaha and co-workers in 2014 developed khajure and mathri snacks were supplemented with cowpea and wheat flour in different combinations. It was noted that khajure and mathri prepared by incorporation of cowpea flour were most acceptable up to levels of $40 \%$ and 20\%, respectively. Further they computed the nutrient composition of cowpea incorporated products and concluded that cowpea supplemented food products may be utilized for solving the problem of protein energy malnutrition among young children in developing countries.

Various studies conducted on cowpea revealed that it an incredible source of many other health-promoting components, such as soluble and insoluble dietary fiber, phenolic compounds and minerals (Liyanage et al., 2014; Mudryj et al., 2012). These nutrients help in improving the quality of human health by offering a number of health benefits. Several studies revels that the consumption of cowpea exerts protective effects against the development of several chronic diseases. Snacks prepared by using cowpea as base ingredient could offer an overall improvement of nutritional status and there by healthy individual especially the young Indian population.

In conclusion this study showed that the cowpea snacks are good source of protein, energy, minerals and exhibits antioxidant activity. Formulation of snacks by using cowpea flours or seed is a major step towards alleviating protein energy and iron malnutrition as most of children and adolescents depend on fried snacks. Children need the protection which is provided by the foods with antioxidant activity. The consumption of cowpea snacks would make some contributions to health promotion and protection required with the advancement in age.

\section{Acknowledgement}

The authors are thankful to UGC's Dr. Dr. S. Radhakrishnan Post Doctoral Fellowship for providing financial support to conduct this work. Authors are also grateful to all the reviewers for his valuable comments to improve the quality of paper.

\section{References}

AOAC. 1995. Official methods of Analysis.16thed, Association of Official Analytical Chemists, Washington D.C.

Bishnoi, R. K. and Brar, S. P. C. 1988. A Handbook of Soil Testing. Punjab Agricultural University, Ludhiyana

Jones MM, Johnson DO, Netlerville JT, Wood JI, Joesten MD. 1985. Chemistry and Society. 5th ed., Saunders College Publishers U. S. A. 521-577.

Kushwaha A., Verma A and Kumar A. 2014. Nutritional Quality Evaluation of Cowpea Supplemented Food Products. Journal of Postharvest Technology.02 (02): 146-151

Liyanage R, Perera OS, Wethasinghe P, Jayawardana BC, Vidanaarachchi JK and Sivaganesan R, 2014. Nutritional properties and antioxidant content of commonly consumed cowpea cultivars in Sri Lanka. J Food Legum Indian J Pulses Res 27:215-217 (2014).

Mudryj AN, Yu N, Hartman TJ, Mitchell DC, Lawrence FR and Aukema HM 2012. Pulse consumption in Canadian adults influences nutrient intakes. $\mathrm{Br} J \mathrm{Nutr}$ 108:27-36 (2012). 
Noor AA, Mohamad AY, Ho L-H. Chemical composition and functional properties of blends of maize and bambara groundnut flours for cookie production. Int Food Res J 2012; 19(4): 1539-43.

Pamela CC, Richard AH, Denise RF. (2005). Lippincotts illustrated Reviews Biochemistry 3rd ed., Lippincott Williams and Wilkins, Philadelphia. 335-388 (for lipid).

Pandey B, Singh JV. Combining ability for yield over environment in cowpea [Vigna unguiculata (L.) walp.]. Legume Research. 2006, 33(3):190-195.

Ranganna S. Handbook of Analysis and Quality Control for Fruit and Vegetable Products, 2ndedn, Tata McGraw Hill Publ. Co., New Delhi, 1986.

Saxena, S.N. Sharma, Y.K. Rathore, S.S. Singh, K.K. Barnwal, P. Saxena, R.
Upadhyaya, P. Anwer, M.M. (2015). Effect of cryogenic grinding on volatile oil, oleoresin content and antioxidant properties of coriander (Coriandrum sativum L.) genotypes. J. Food Sci. Technol. 52: 568-573.

Shimada, K. Fujikawa, K. Yahara, K. Nakamura, T. (1992). Antioxidative properties of xanthinon autoxidation of soybean oil in cyclodextrin emulsion. J. Agric. Food Chem. 40: 945-948.

Verma A., Kushwaha A., Kumar A. and Baghel S. S, 2019. Physico-chemical properties and nutritional composition of improved varieties of grain cowpea grown in Pantnagar. Journal of Pharmacognosy and Phytochemistry 2019; SP5: 334-338.

\section{How to cite this article:}

Dashrath Bhati and Rita Singh Raghuvanshi. 2020. Nutritional Quality Evaluation of Popular Indian Fried Snacks Based on Cowpea. Int.J.Curr.Microbiol.App.Sci. 9(09): 650-655. doi: https://doi.org/10.20546/ijcmas.2020.909.082 